\title{
On the Use of Perspective in a Drawing Attributed to Diego Siloé
}

\author{
Antonio Ampliato ${ }^{1}$ (1) Eduardo Acosta ${ }^{1}$ (])
}

Published online: 10 June 2020

(c) Kim Williams Books, Turin 2020

\begin{abstract}
The drawing analysed in this article, conserved at the MNAC in Barcelona and attributed to the Spanish architect Diego Siloé (ca. 1490-1563), has never previously been studied in depth. It is a relatively rapidly executed sketch depicting a Renaissance urban setting, in which the authors not only demonstrate the sound use of one-point perspective, an extraordinary feat in Spain at that time, but also reconstruct it geometrically. Raking light photography provides a tool for identifying numerous incised lines, the true geometric support for the drawing, while a comparative analysis reveals a significant connection between the drawing and Siloé's works, giving rise to new suppositions. The authors also detect a strong connection with Italy, consistent with existing hypotheses about the extent of the young Siloé's Italian sojourn. The research conducted reinforces the attribution of the drawing to Siloé and opens up new channels for interpreting his life and work.
\end{abstract}

Keywords One-point perspective drawing · Renaissance architecture · Diego Siloé · Geometric reconstruction

\section{Introduction and Aims}

This article analyses an architectural drawing attributed to the Spanish Renaissance master Diego Siloé (Fig. 1) held at Museu Nacional d'Art de Catalunya (MNAC). ${ }^{1}$ It is a perspective drawing in which the foreground shows a porticoed passage with classical columns and a fluted barrel vault. Behind this, another building displays

\footnotetext{
${ }^{1}$ Inventory number: 107786-D. We are sincerely grateful to this institution and, in particular, to Francesc Quilez Corella, chief curator of drawings and prints, for allowing us to study and reproduce the drawing.
}

Eduardo Acosta

eduacosta@us.es

Antonio Ampliato

alab@us.es

1 University of Seville School of Architecture, Seville, Spain 
Fig. 1 Architectural drawing attributed to Diego Siloé, Museu Nacional d'Art de Catalunya (MNAC), inv. number 107786-D, reproduced by kind permission

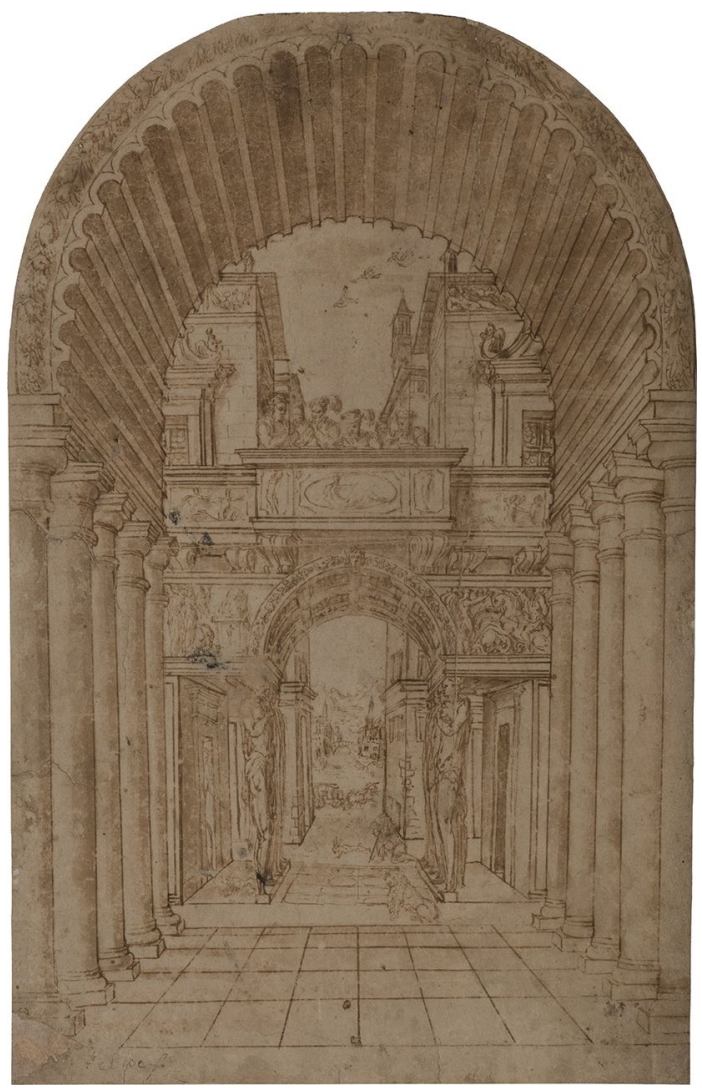

a relatively complex volumetric composition, with a second porticoed passage featuring caryatids and atlases at the base and a system of balconies at the top, the central one with musicians. In the background, an urban landscape with a river is framed by high mountains. The elements of the drawing do not seem to correspond to any real space and may therefore be considered an architectural fantasy.

It is a small ink and wash drawing on thick, somewhat deteriorated paper, measuring $39.9 \times 25.6 \mathrm{~cm}$. At the lower left corner, in a different ink, there is a symbol (possibly a flourish) followed by two words, the second one partly erased: "Siloe fe[...]", which we could interpret as "Siloe made it". The handwriting differs from that of the numerous manuscripts by the master that have been preserved (Fig. 2), and may be ascribed to a wide time frame between the sixteenth and eighteenth centuries, possibly when the drawing became part of a private collection. ${ }^{2}$ The surname also differs from how the master used to spell it: "Siloee", with double

\footnotetext{
${ }^{2}$ On palaeographic aspects, we are thankful for the advice of Pilar Ostos Salcedo and Carmen del Camino Martínez, professors of the University of Seville.
} 

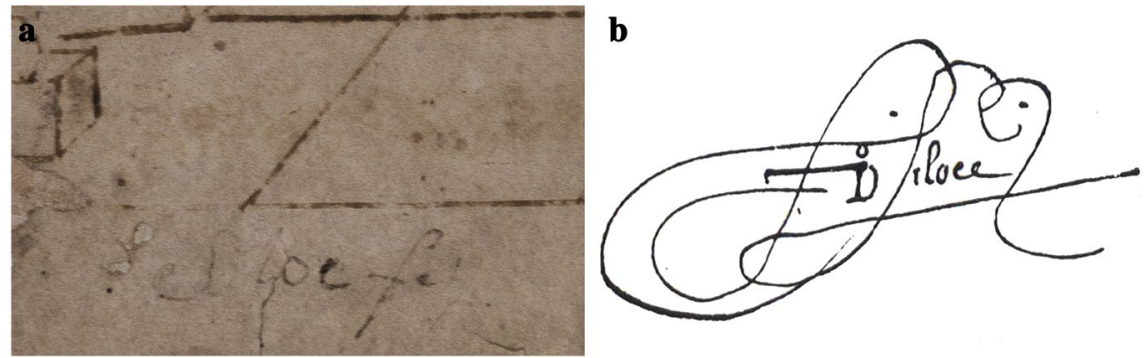

Fig. 2 a MNAC drawing, detail of the annotation in the bottom left corner of Fig. 1; b handwritten signature of Diego Siloé in 1547 (Gómez-Moreno 1988: 60)

"e", in keeping with the Flemish origin of his surname. ${ }^{3}$ We know that when he died in 1563, Diego Siloé left a large number of "tracings and drawings of both architecture and figures" (Gómez-Moreno 1988: 63) which could have ended up scattered among different collectors (Pérez 1986: 81). In spite of what the document itself shows, proof of its authorship has not been sufficiently substantiated. ${ }^{4}$

The bibliography about the drawing held by the MNAC is scarce. ${ }^{5}$ For Miguel Falomir (2000) the drawing is a scenographic perspective, something unusual in Spain in the first half of the sixteenth century. ${ }^{6}$ More recent studies (Frommel and Parada 2014: 304; Parada 2018: 183) relate the drawing to the triumphal entrances of Emperor Charles V, one of which took place in Burgos in 1520 with a series of arches designed by Diego Siloé himself. These authors point out the character of imperial exaltation of the Serlian motif that occupies the center of the composition, enhanced by the abundance of bas-reliefs and the presence of musicians. Finally, they recall the frequent use of the Serlian motif by Siloé, both in Burgos and Granada, and the Granada multifoil cusped arch evocation of the fluted barrel vault in the foreground.

\footnotetext{
${ }^{3}$ Gómez-Moreno (Gómez-Moreno 1983: 41) states that the master always wrote "Siloee", with a double "e", and also that the usual pronunciation would have put the stress on the "o", as there are a diversity of ways in which hands other than the master spelled his last name. However, whether or not this last deduction is correct, the Flemish pronunciation of the term "Siloee" is equivalent in current Spanish to that of "Siloé", with an accent on the last vowel, a form commonly used by many other researchers and shared by us. On the other hand, Gómez-Moreno also asserts that the preposition "de" placed between the first and last name (many researchers write "Diego de Siloé") does not appear in the sixteenthcentury documents, for either Diego or for his father Gil. Considering the unquestionable fact that the master himself always wrote with his hand "Diego Siloee", we believe that the current equivalent form is "Diego Siloé".

${ }^{4}$ In the MNAC catalogue, the drawing is recorded as purchased in London in 1964 by Xavier de Salas Bosch, director of the Spanish Institute and secretary of the Board of Museums of Catalonia, possibly from an antique dealer. A reproduction of the payment can be found in Arxiu Nacional de Catalunya, ref. ANC1-715-T-6284.

${ }^{5}$ See Garriga (1988), Falomir (2000), Ortega (2001), Frommel and Parada (2014) and Parada (2018).

${ }^{6}$ The first important scenic apparatus, probably with a perspective set, was documented in 1548 (Ferrer 1991: 59ff., specially $75 \mathrm{ff}$.).
} 

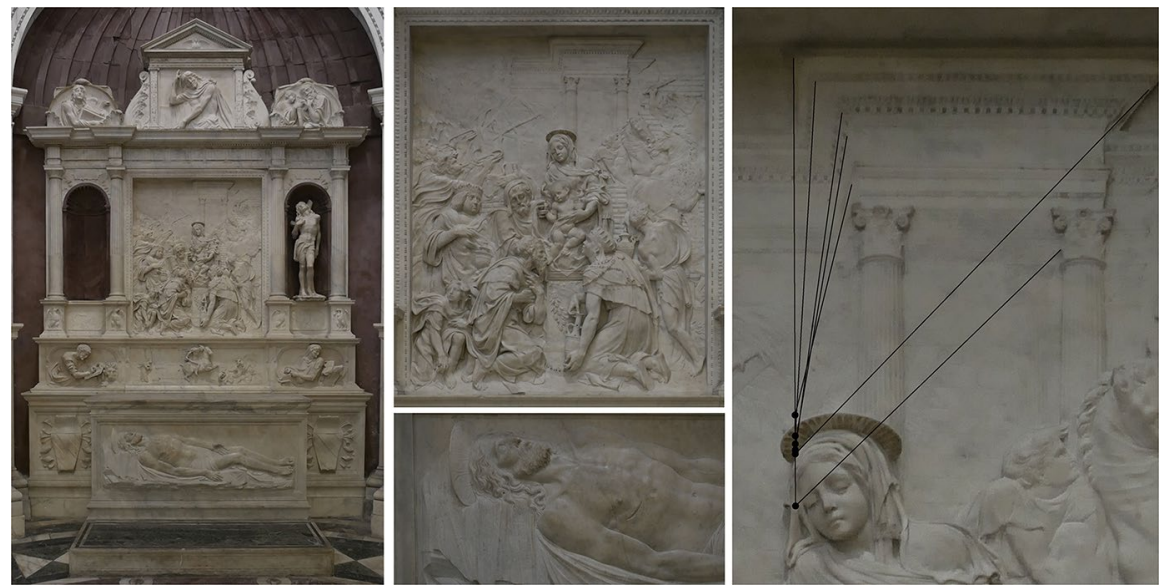

Fig. 3 Bartolomé Ordóñez and Diego Siloé, altar in the Caracciolo di Vico Chapel in San Giovanni a Carbonara, Naples, before 1517, general view and details

Our aim here is to analyse the graphic, geometric and conceptual design of the drawing and the architecture depicted. Although we cannot aspire to arrive at a definitive conclusion, we hope to contribute to reinforce existing knowledge about the possible authorship of the drawing and to find possible relations with the life and work of Diego Siloé.

\section{On the Presence of Diego Siloé in Italy and the Use of Perspective}

Diego Siloé was born in Burgos around 1490 and began his training under his father, the Flemish-born sculptor Gil Siloé. After his father's death, circa 1505, Diego Siloé continued his training with the sculptor Felipe Bigarny but appears to have left this workshop in 1508 (Hernández 2000: 101-116). The next information available places him in Naples before 1517, along with his fellow countryman Bartolomé Ordóñez (ca. 1490-1520), both responsible for the main altar in the Caracciolo di Vico chapel in San Giovanni a Carbonara (Fig. 3).

The professional relationship and friendship between the young sculptors provide a crucial insight into several important aspects of Siloé's training. In his will, Ordóñez refers to Diego Siloé as his "partner" and names the works they have in common. Bartolomé Ordóñez had a meteoric but short-lived career distinguished by the fine quality of his work. He maintained a substantial professional relationship with a number of Florentine artists, including some in Michelangelo's circle (Gómez-Moreno 1983: 25). In addition to the Caracciolo altar, several scholars have proposed numerous plausible attributions based on technical or stylistic criteria, to the two masters during their sojourn in Naples (Naldi 2018). Ordóñez and Siloé must have been in Italy from some time before 1514, the beginning of the time frame for the Neapolitan attributions (Naldi 2002: 172-178), until December 1517, when a document confirms that at least Ordóñez was still in Naples, buying Carrara marble 
Fig. 4 Diego Siloé, Golden Staircase in Burgos Cathedral, 1519

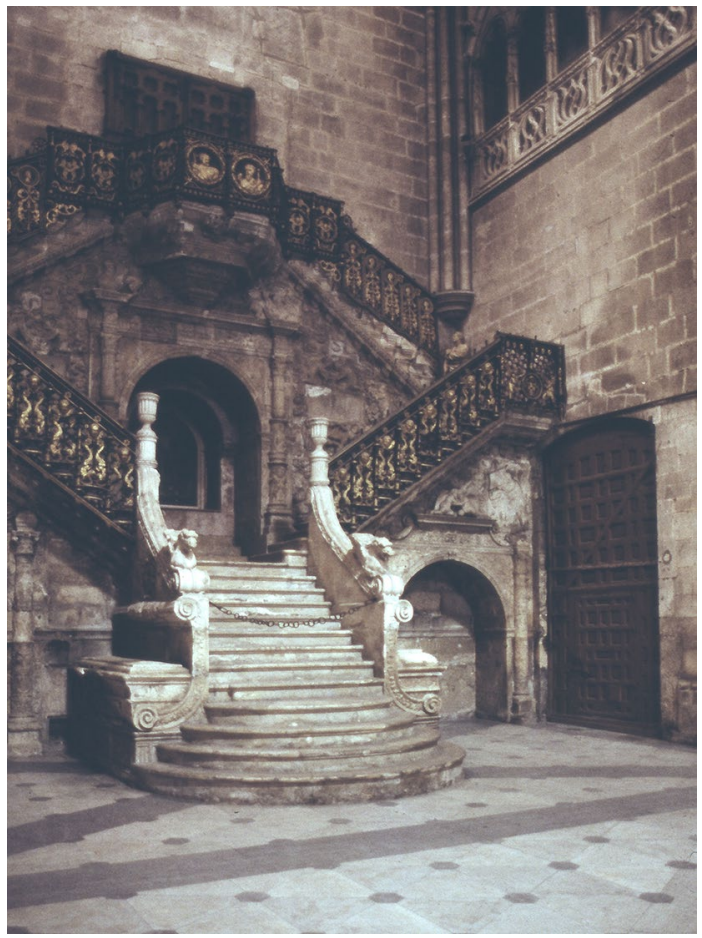

for the cathedral retrochoir of Barcelona before departing for that city (Zurla 2013: 132-145). Siloé was back in Spain in 1519, designing the Golden Staircase for the cathedral of Burgos (Fig. 4), a seminal work for the introduction of the Renaissance in Spain (Gómez-Moreno 1983: 45).

However, an interesting aspect takes us much further: the bas-reliefs of the Caracciolo altar reveal the use of a foreign and unique craftsmanship, the schiacciato, ${ }^{7}$ which suggests a possible internship of Ordóñez and Siloé in a Florentine workshop (Naldi 2018: 14-23, 38 and 139), and prompts new hypotheses about the possible learning of other relevant techniques in Italy, including the advancements in perspective drawing. It should be borne in mind that schiacciato and perspective are two very different technical resources, but they share a coherence in their purposes. In fact, perspective is present in the bas-relief of the Caracciolo altar, in the background building with classical orders that emerges behind the figures. It is true that this architectural fragment occupies a secondary place, as it is also true that the perspective convergence (difficult to evaluate precisely) affects a small group of lines (see Fig. 3). In spite of everything, the presence of perspective and schiacciato in the same piece is, in our opinion, a relevant piece of evidence that Bartolomé Ordóñez and Diego Siloé received a solid training during their stay in Italy.

\footnotetext{
7 An extremely low relief technique in which very shallow recesses create a sensation of depth.
} 

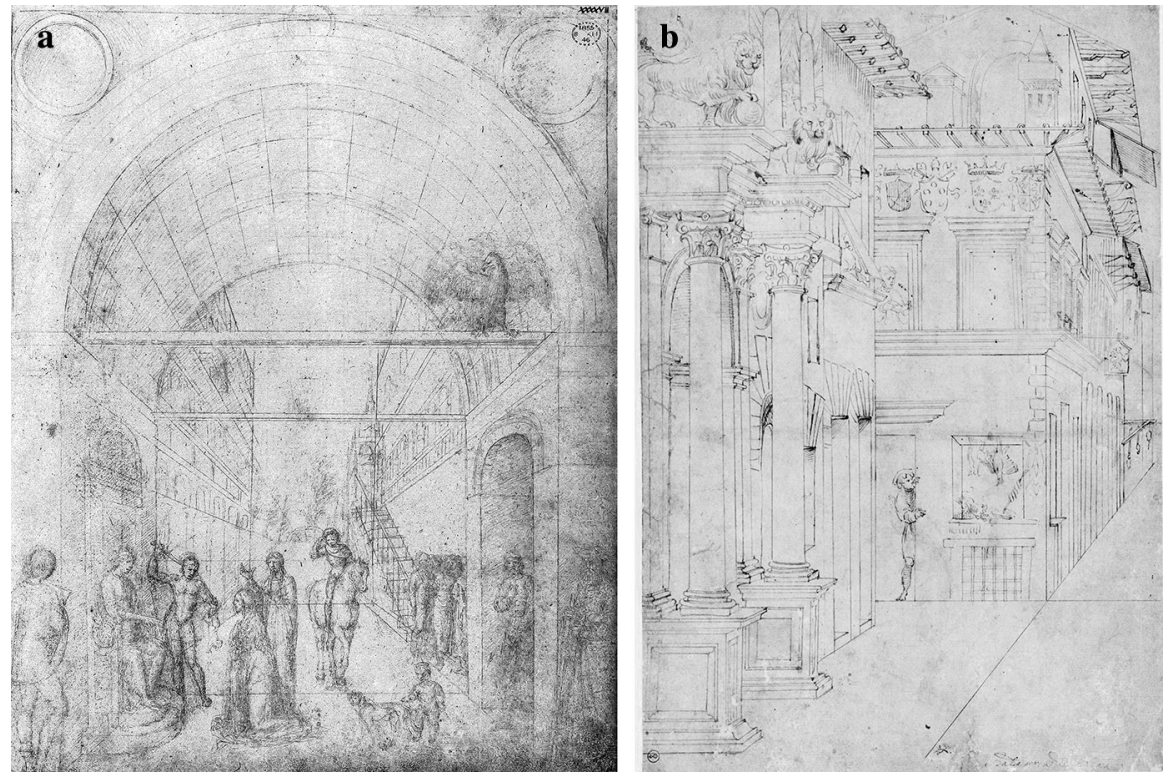

Fig. 5 a Jacopo Bellini, The Jacopo Bellini album: The Judgement of Solomon, recto (British Museum, London, inv. 1855, 0811.46); b Baldassarre Peruzzi, comedic stage set, 1515 (Biblioteca Reale, Turin, inv. 15728.IT.45)

Considering the evolution of perspective in Europe, the Italian experience in the fifteenth century made a major conceptual difference: the use of a horizon line, single vanishing point and proportional control of depth. As a result, this implied an awareness of the abstract, three-dimensional and infinite nature of space, a sophisticated conception that only began to emerge in other areas of the continent, very slowly, at the start of the sixteenth century (Panofsky 1998: 9-27). The way perspective arose in Italy during the fifteenth century constituted a powerful and innovative field of experimentation for artistic creativity, including the symbolic use of geometric convergence (Panofsky 1983: 47-48). In numerous perspective depictions, as in the drawings of Jacopo Bellini (Fig. 5a) or in the paintings of Piero della Francesca, the new architecture appeared significantly in a great diversity of urban scenes. These representations contributed to the development of a long-lasting new way of conceiving urban space. The drawing of the MNAC could perfectly be related to this, especially if we take into account a real experience such as the aforementioned participation of Siloé in the design of the triumphal entry of Carlos $\mathrm{V}$ in Burgos.

The advancements of the art of scenography at the beginning of the sixteenth century ushered in a new field of experience in the practice of perspective in relation to the city. A fundamental milestone in its evolution was the presentation in the Vatican palaces of the comedy La Calandria in 1515. Baldassare Peruzzi's scenographic design for this play managed to condense an imaginary Rome by means of a complex perspective design that embraced the whole of the stage space. As can be noticed in Peruzzi's drawings, the practice of perspective scenography 
was to develop specific techniques for the creation of three-dimensional elements (Poggi 2005; Steadman 2020), a purpose evidently alien to the drawing preserved in Barcelona. Nevertheless, the analysis of the scenography for La Calandria and other of his works, only partially preserved (Fig. 5b), also reveal the development of a visual rhetoric that turns the space represented into a place of architectural experimentation (Hara 2016: 587-596), something that we can undoubtedly discern in the drawing that is the object of our research. It is worth remembering that the presentation of La Calandria in Rome is fully within the possible time frame of Siloé's sojourn in Italy. Of course, Siloé's presence in Rome and his familiarity with the preparations for this event are merely conjectural. In any case, this is not the first time that Peruzzi's name appears related with Siloé's work: in regard to his project for the Cathedral of Granada, Manfredo Tafuri had already raised the possibility that the Burgos master might have had first-hand knowledge of Peruzzi's designs for Saint Peter's (Tafuri 1992: 248).

All these special characteristics of the advanced Italian experience in architecture and perspective representation at the beginning of the Modern Age constitute, for us, an important resource for confirming a direct and deep contact between Italy and the author of the MNAC drawing, and to understand the possible scope of this work. During the Spanish Late Gothic, the master painters relied heavily on the Flemish tradition, which did not use an exact scientific system but offered only an approximation to a certain sensation of reality (Domínguez 1992: 195-204). Until the late sixteenth century, the Italian use of perspective had scant repercussions in Spain, remaining virtually absent from the local treatises (González 2006: 33-70). In fact, the numerous Spanish manuscripts and treatises on architecture continued to obey the ancient and medieval optics, diversifying the vanishing points for a single family of straight parallel lines (Gentil 1998: 218-234). All these circumstances place Diego Siloé in a special position within the Spanish context.

\section{Incised Lines, Ink Lines and Geometric Reconstruction of the Perspective Space}

The drawing of the MNAC contains two types of lines: those drawn in ink and the practically invisible ones incised with a stylus. Our first aim was to identify and transcribe all of these crucial incised lines for the geometric analysis of the perspective structure and, therefore, for the possible geometric reconstruction of the three-dimensional space depicted. Raking light photography (RAK) was used to detect and document incised lines in the drawing. ${ }^{8}$ Lastly, we transcribed everything to a CAD file on a rectified photograph of the drawing (Fig. 6). The result reveals the liberal use of a ruled support, compatible with the freshness of a natural execution, placing the drawing midway between technical precision

\footnotetext{
${ }^{8}$ It was sometimes difficult to distinguish them from the mark left by the pen on the paper. We overcame this difficulty by only validating as incised lines the ones that were visibly longer than the corresponding ink line. A certain number of incised lines have probably not been detected or preserved.
} 

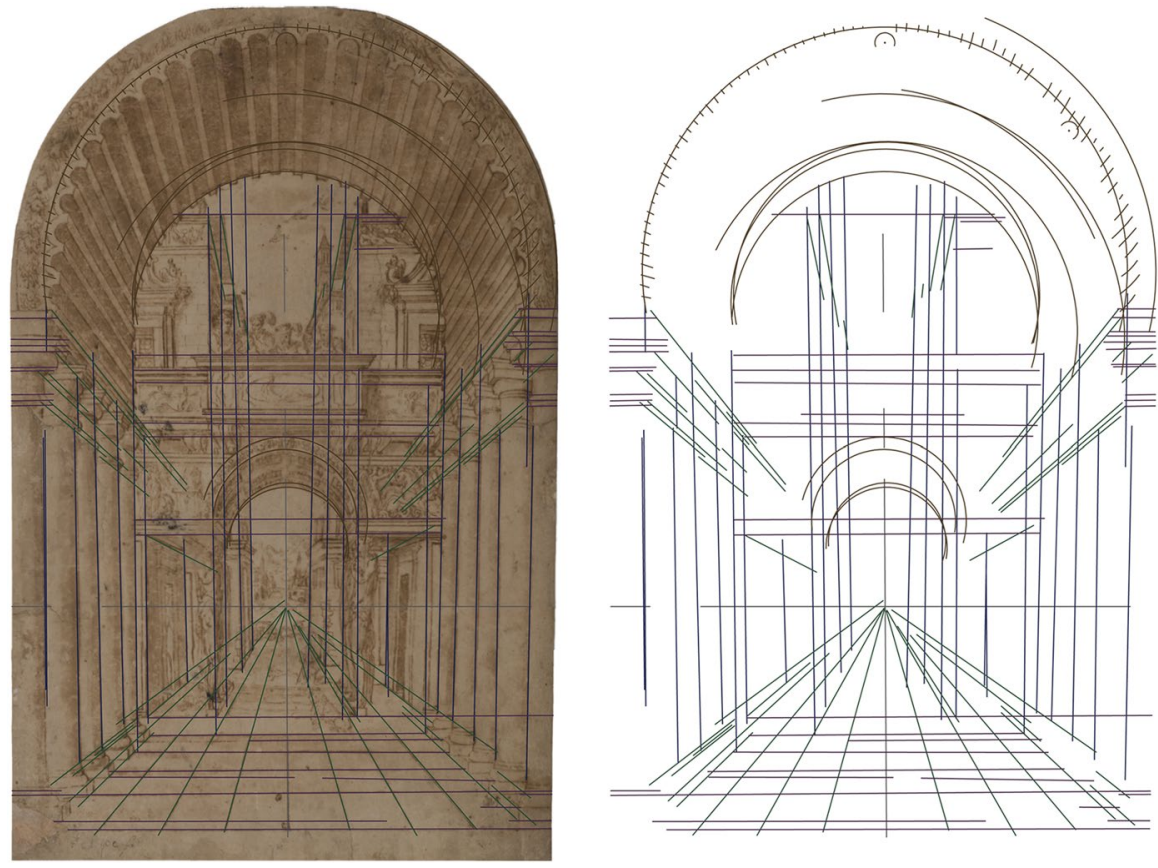

Fig. 6 Transcription of the incised lines on the MNAC drawing
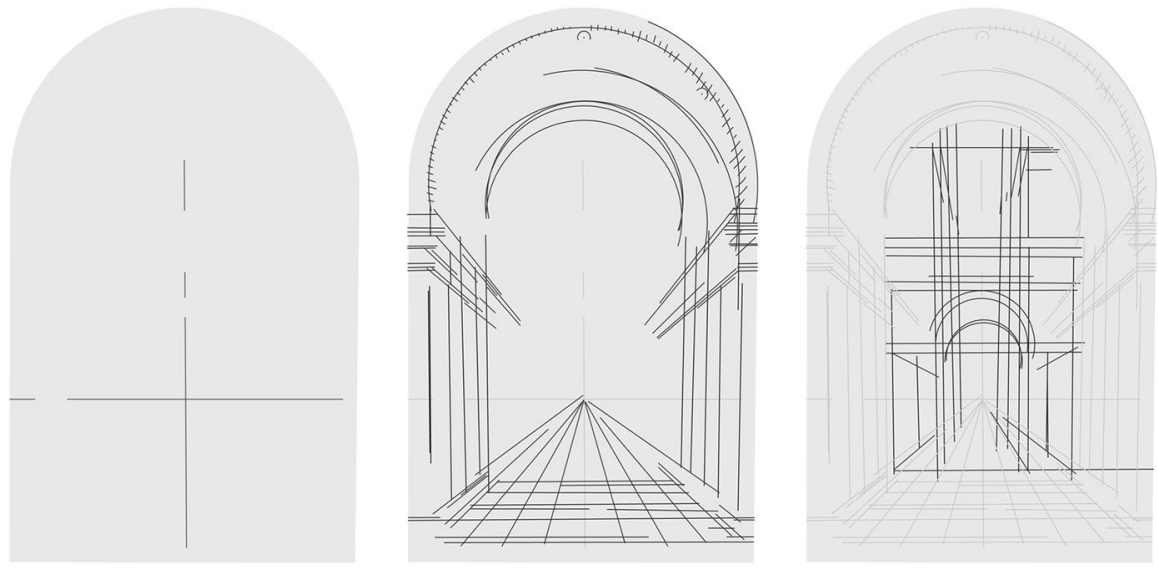

Fig. 7 Hypothesis about the order of execution of the incised lines

and freehand sketching. All the geometric operations (convergences, parallelisms, perpendiculars, symmetries, etc.) lack absolute precision but are sufficiently controlled. A few of the ink lines take geometric liberties that are not found in the incised lines, all of which are always guided. The overall drawing has a clear and highly coherent single vanishing point. We describe the incised lines in three 
steps (Fig. 7), based on an order of presentation that also serves as a hypothesis about their order of execution.

Firstly, the horizon line, from edge to edge of the paper, is perfectly identifiable, together with a perpendicular line (angle of $89.65^{\circ}$ ) that reinforces the main vanishing point and set the position of the observer within the general symmetry of the composition (Fig. 7a). These are the only two purely abstract incised lines, as they do not support the subsequent figurativeness of any object. For a relatively rapidly executed drawing, these first two lines were traced with careful precision. The next set of incisions is situated in the perimeter of the paper, establishing the first references for all the elements in the foreground. The first vanishing lines recede from here (Fig. 7b). Then come the vertical and horizontal subdivisions and the various arcs for the first vault, some of which were dismissed. The convergences, parallelisms and perpendiculars are now only approximate. The last group of incised lines corresponds strictly to the mouth of the first passage, which suggests a subsequent execution (Fig. 7c). The emphasis is now frontal, and the very few vanishing lines that exist are correctly executed but not always respected in ink, revealing a certain relaxation of geometric rigour. In short, this is a perspective drawing with a central vanishing point whose technical execution already suggests several clues to its composition: two successive sections, the first strictly architectural with greater geometric precision and the second with figures, objects and landscapes executed with less geometric precision.

The geometric reconstruction of the space can only be approximate for a drawing of this nature, but it will provide a valuable tool for analysing the spatial knowledge and skills deployed. We will begin by identifying some real dimensions according to the picture plane, then we will look for evidence of a certain geometric control of depth, and lastly, we will calculate the value of some measurements perpendicular to the picture plane so that we can reconstruct the space in three dimensions.

To assess whether it is possible to measure the entire space according to the picture plane, we first confirmed that the horizon line (the plane that passes through the observer's eye) intersects all the elements at a determined height. In the portico with human figures, a rapidly executed silhouette enters the scene from a door on the left (see Fig. 6) and his eyes are situated slightly above the horizon line. His height is very similar to that of the more carefully rendered musician standing at the left corner of the balcony, slightly closer to the observer. Therefore, assuming that the horizon is situated at the height of a person, the vanishing lines of the lower entablatures and door lintels, and the general space of the street, seem to be fairly coherent. In view of all of these factors, we believe it is reasonable to use an anthropometric reference to situate the horizon line at a height of $1.60 \mathrm{~m} .{ }^{9}$ This implies a total height of $3.62 \mathrm{~m}$ for the column and a span of $3.60 \mathrm{~m}$ for the mouth of the vault, resulting in a practically square ratio for the opening. The keystone would be situated at $5.78 \mathrm{~m}$.

\footnotetext{
9 Approximate height of the eyes for a 6-foot statue, a classical reference used by Pedro Mexía in his Silva de varia lección published in Seville in 1540 (Sánchez 2012: 22).
} 

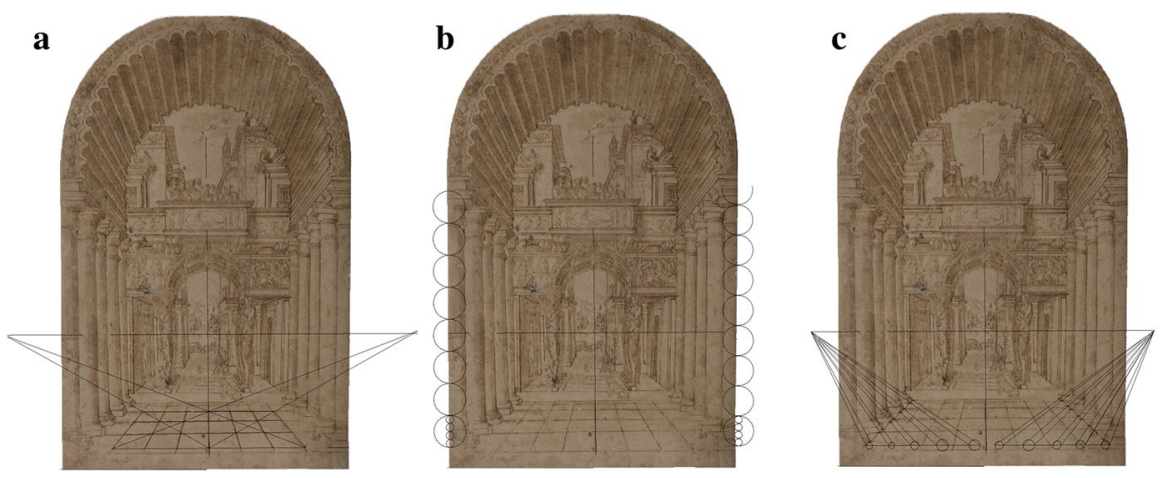

Fig. 8 a Perspective geometric control of the grid on the floor; $\mathbf{b}$ estimation of the shaft diameter and column height; c estimation of the intercolumniation-shaft proportion in the porticoes

The next step is to establish the existence of a certain knowledge of the geometric control of depth. We will do this on the grid on the floor, including some of the noninked incised lines (see Fig. 6). At first sight, this grid reveals a complete absence of regularity. However, if we ignore the first inked line and include the first non-inked incised line, both bottom horizontal, the first three rows of tiles reveal diagonal lines that recede with considerable geometric regularity, albeit, as with everything else in the drawing, without absolute precision (Fig. 8a). The appearance of this single regularity in a series of graphical variations of the grid, whose meaning is impossible to decipher, confirms the general impression produced by the drawing as well as the fact that the author had a certain awareness of the geometric law of the variation of size with distance.

Lastly, we will look for some measurements perpendicular to the picture plane in the series of the columns in the first passage. These columns are midway between Tuscan and Doric. In the modern treatises both of these orders tended to maintain the initial Vitruvian ratio of seven diameters in height, including the base and the capital for the Tuscan column (shaft of six diameters) and only the capital for the Doric version without a base (shaft of six and a half diameters). Naturally there were variations, such as the eight diameters for the Tuscan column that Serlio proposed as a lighter option in his Book IV in 1537 (Serlio 1537), or, to take a significant practical case and one relatively close in scale, the eight diameters of the Doric columns in Bramante's Tempietto of 1502, which would become increasingly frequent. With regard to Tuscan intercolumniations, originally undefined, Vignola in 1562 (Vignola 1985) dictated two diameters and one-third, while in 1570 Palladio (1980) drew four diameters. Doric intercolumniations were more regulated and varied between two and a half diameters and two and three quarters diameters, values close to the Eustyle described in Book III of Vitruvius, although in practice other options were used such as, going back to Bramante, the three diameters of his Tempietto, which lend an extraordinary lightness to the work.

Bearing these references in mind, we calculate the ratios of the columns in the drawing using a rule that remained practically intact throughout the sixteenth century: 
the height of the plinth is a quarter of the diameter of the shaft. Operating graphically on the first two columns, we can estimate the diameter of the shaft and then the total height of the column (Fig. 8b). The ratio of the column on the left is almost exactly eight diameters, while the ratio of the column on the right is just over eight and a half diameters, both of which are quite satisfactory in a drawing that contains so many freehand elements. Taking the ratios of the column on the left and considering the total height previously obtained, we have a shaft diameter of $0.45 \mathrm{~m}$.

To calculate the intercolumniations we can try to unravel the perspective with Thales' theorem, dragging the series of columns proportionally to a front line (Fig. 8c). Operating with the plinths, with more accurate graphical references, we can deduce the shaft ratios. This produces proportional series for both porticoes which, in our opinion, reveal a surprising regularity, bearing in mind the enormous dimensional deviation that a drawing can present when we try to intuitively proportion the perspective depth. Calculating a statistical average for both series, we obtain a final intercolumniation of three and a quarter diameters.

All the values obtained enable us to create a geometric reconstruction of the space depicted, calculating the position of the viewpoint on the basis of the diagonal line of the passage, in plan and perspective, which is situated $12.17 \mathrm{~m}$ from the mouth of the vault (Fig. 9). Lastly, we can reverse the entire conical projection to calculate the true scale of all the elements, assuming the level of reality or unreality they intrinsically possess (Fig. 10). With the line of sight marking the height of the observer in the image, the result is surprising because of the great coherence in the proportions and dimensions of all the elements, from the nearest to the farthest, including the two final three-story buildings. In our opinion, the drawing is the work of a person with an excellent control of perspective and a remarkable familiarity with the classical language, applied here with a relatively fast execution and no intention of absolute precision.

Moreover, the perspective of the barrel vault in the first passage is intentionally misleading. Two virtual models have been portrayed to demonstrate this (Fig. 11). It is possible to observe the effects of both a regular fluted barrel vault (Fig. 11c) and the actual barrel vault, with the cant considerably more pronounced towards the background (Fig. 11a). The drawn version of the vault is clearly attempting to create a wider panorama of the bottom. In fact, the vault is an oblique half-cylinder, completed by the vertical tangent planes. On such a forced volume, the perfect perspective convergence of the flutes in the vault in the drawing is actually a trompe l'oeil that only works efficiently from the main viewpoint. The real flutes would be warped lines in space, with a geometric complexity which the author of the drawing clearly did not seek. The various alternatives used for the vault give rise to a number of incised arcs which were dismissed (see Fig. 6), highlighting the flexibility and malleability adopted for this architectural composition as we will see in the following section.

\section{Analogies Between the Elements of the Drawing and Siloé's Work}

Many of the characteristics of the architecture depicted in the MNAC drawing are analogous to those found in Diego Siloé's work. The first specific work we will consider is one of the many stained-glass windows in the chevet of Granada 
Fig. 9 Calculation of the real position of the viewpoint in the space depicted in the drawing
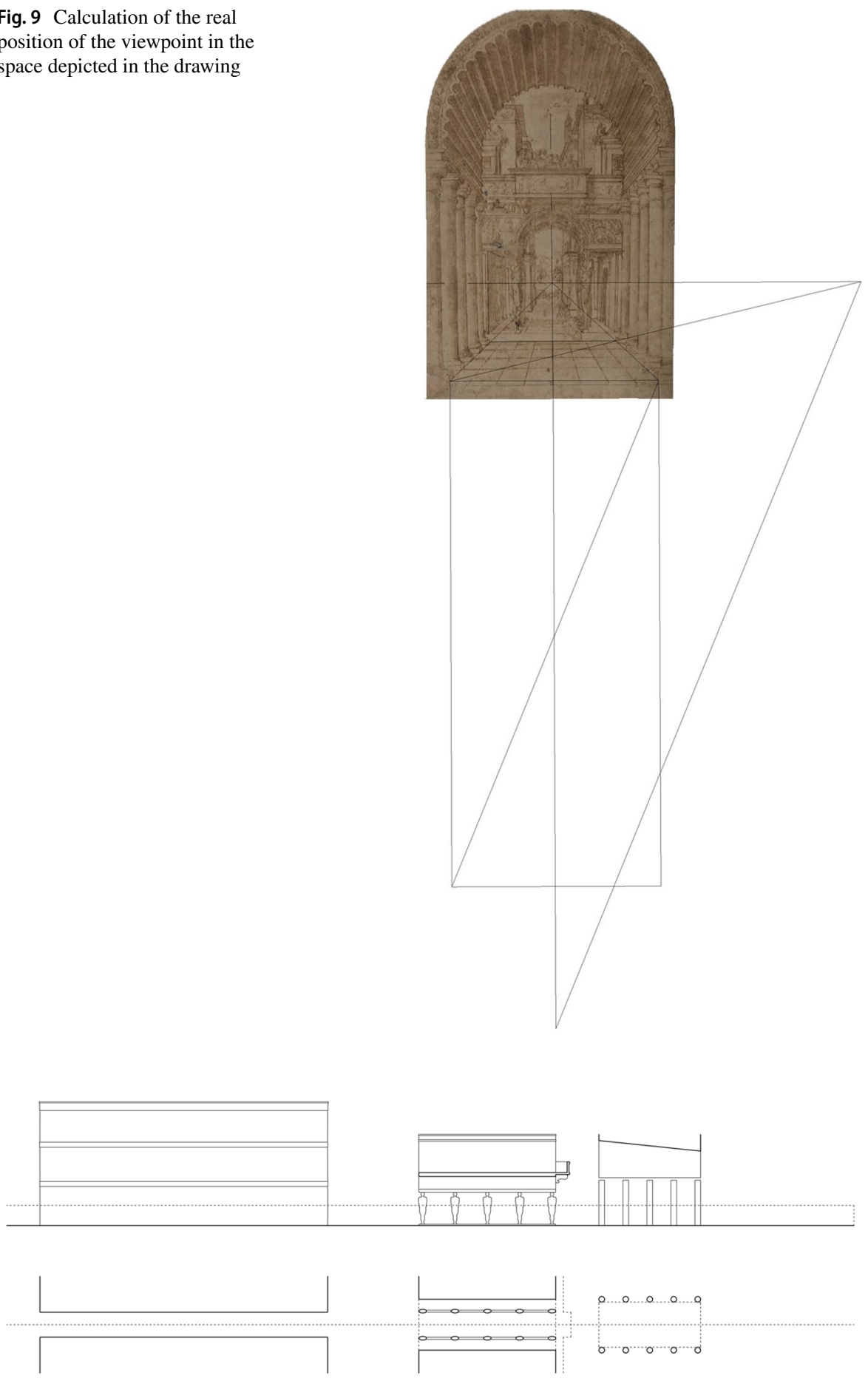

Fig. 10 Reconstruction of the plan and section of the space depicted 

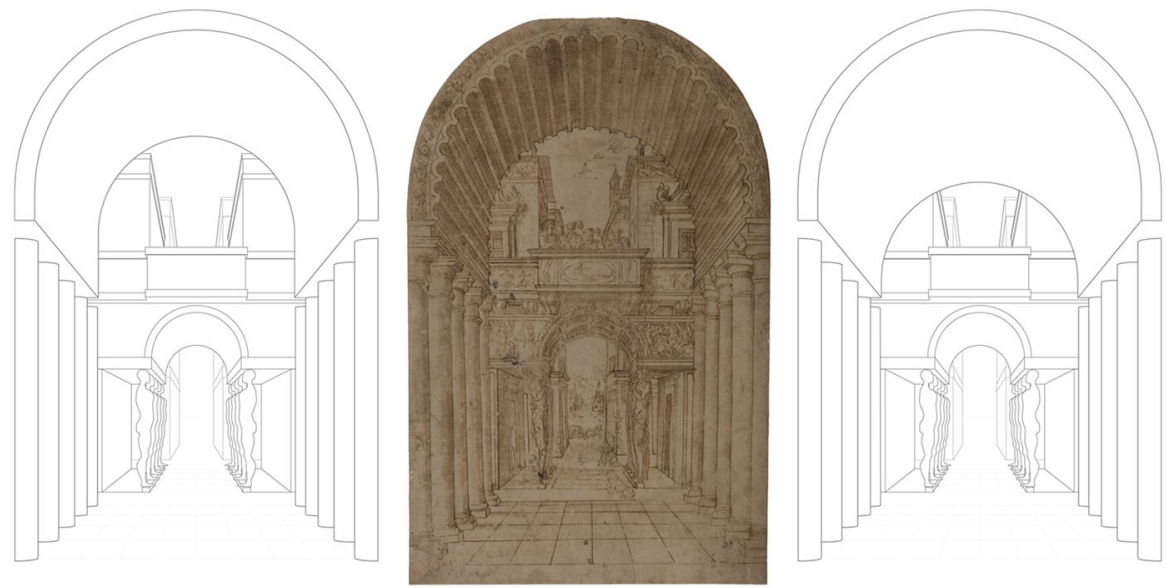

Fig. 11 Left: virtual photographs of the simplified 3D model, with the manipulated barrel vault shown in the drawing; right: a theoretical regular barrel vault

Fig. 12 Diego Siloé (outline, 1554) and Juan del Campo (execution, 1558-60), stainedglass window of Our Lady of Sorrows in Granada Cathedral, image reproduced from (Nieto 1973: 80) and processed by the authors to correct an error in the original execution

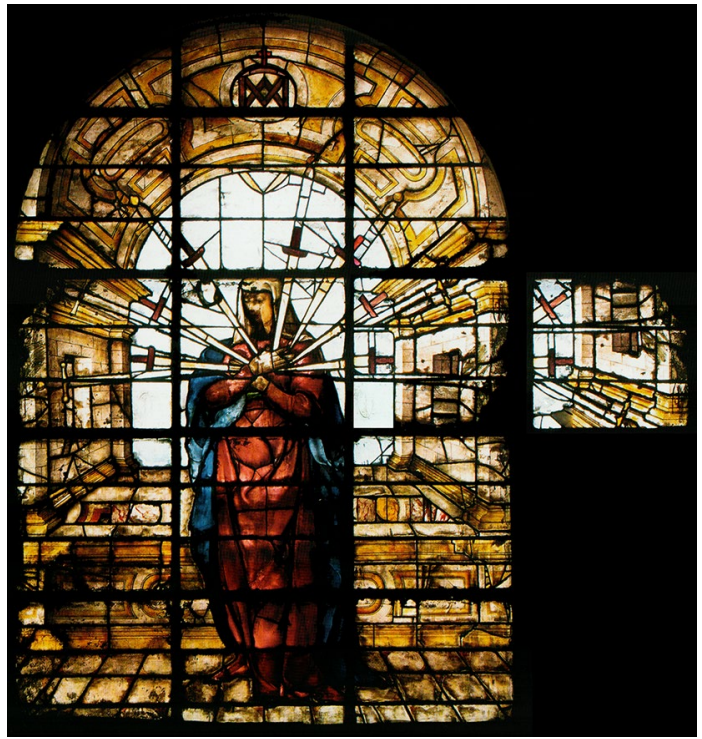

Cathedral, whose outlines Siloé was commissioned to make in 1554 (Gallego 1936: 347). The process for making a stained-glass window implied making a drawing for approval by the cathedral council and then repeating it as a full-size cartoon. Next, pieces of glass were cut and laid over this cartoon to transcribe the image (Nieto 1967: 267-274). The stained-glass windows in Granada Cathedral include a variety of architectural fragments, but one of them in particular contains exceptional compositional characteristics. It is the stained-glass window of Our Lady of Sorrows, installed by Juan del Campo between 1558 and 1560 (Nieto 1973: 82). 

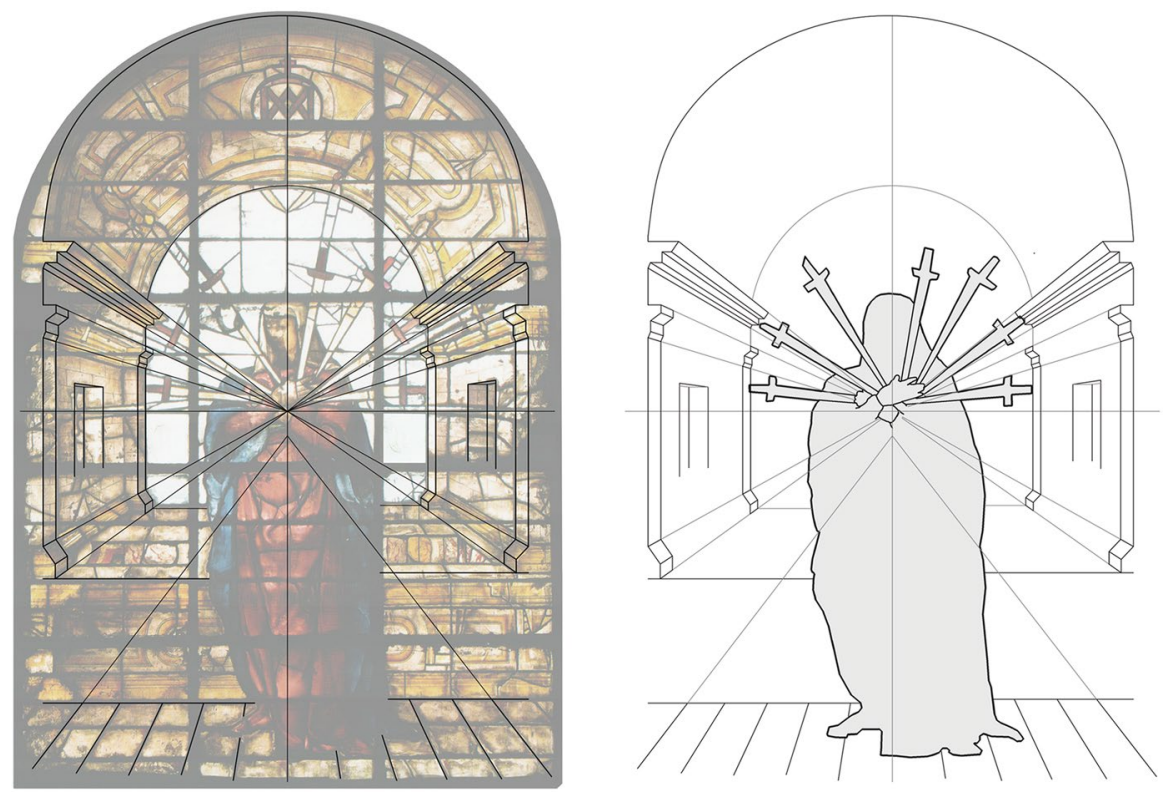

Fig. 13 Perspective analysis of the stained-glass window of Our Lady of Sorrows

To obtain the original image we have had to photographically correct a mistake that was made during its execution (Fig. 12). The right-hand central square (reproduced separately) shows a mirror inversion according to the horizontal axis which affects the wall elements (capitals and cornices) but not the hilts of the swords. By selectively undoing this mirror inversion, without making any other adjustments, the image obtains a perfect symmetry.

The window depicts an architectural space with a barrel vault and our Lady of Sorrows at the centre. Most significantly, it uses a central viewpoint perspective sculpturally and with enormous expressiveness in spite of its schematic nature (Fig. 13). We can see that many of the main lines conform to the rules of perspective, while others ignore them, probably due to an incorrect transcription from the original drawing. One of the leaded lines serves as the horizon line while a perpendicular one establishes the position of the vanishing point, which is situated over the heart of our Lady of Sorrows, an expressive use of perspective that we referred to above and rarely found in Spain. The fan of swords turns the geometry of lines converging to the vanishing point into an instrument for introducing pathos in the image. Some of the analogies with the MNAC drawing are obvious: a perspective barrel vault, aligned with the outer edge of the image, surrounds a central scene which, in spite of being situated closer to the observer in this case, is still subordinated to the architectural frame. In fact, we can see the traces of some longer original swords that were ultimately replaced by the definitive ones with red hilts, fitted within the subsequent mouth of the barrel vault.

The place where this stained-glass window is located, the chevet of Granada Cathedral, is also its principal reference. Granada Cathedral is Diego Siloé's 

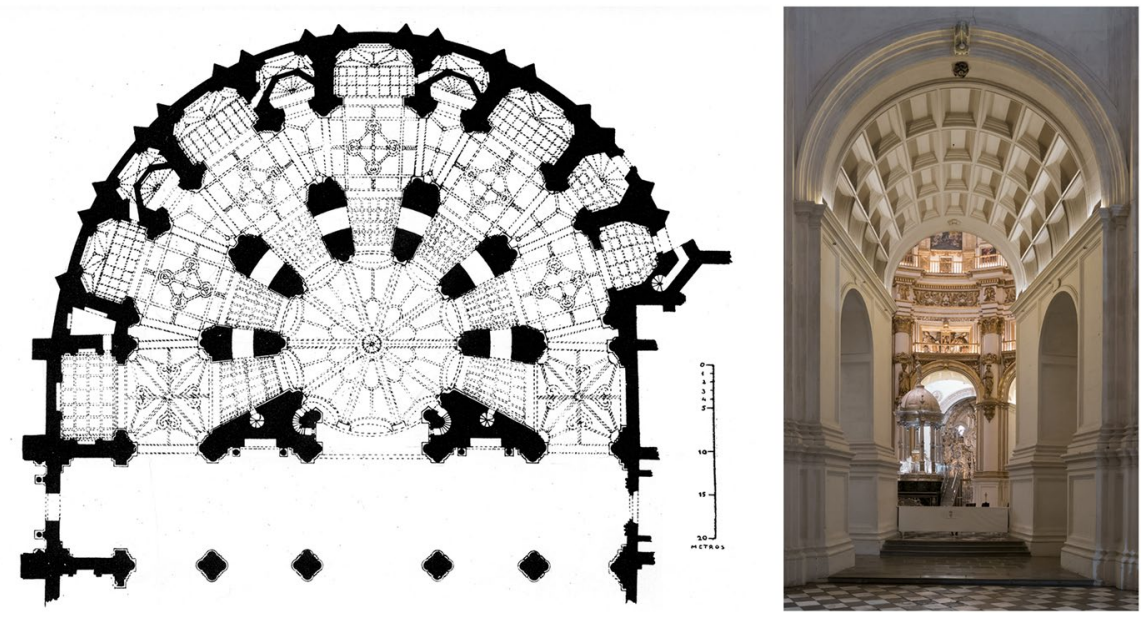

Fig. 14 Diego Siloé, Granada Cathedral, after 1528, plan of the chevet (Gómez-Moreno 1983: 69) and detail of the passages

masterpiece, a commission received in 1528 in which the master gave great prominence to a fan of radial passages around the main altar. We believe that on an abstract level, the compositional and symbolic analogies between the stained-glass window and the chevet plan are fairly evident (Fig. 14a). The cathedral has been analysed over the years by leading scholars (Gómez-Moreno 1983; Rosenthal 1990; Tafuri 1995) highlighting the imaginative and innovative solution of combining a central typology with a basilica type, the autonomous spatial conception of the chevet (the only section completed in Siloés lifetime), the superimposition of a geometric centrality and liturgical centrality, and the powerful visual permeability afforded by the radial passages.

Each of these passages, gazed at from the ambulatory (Fig. 14b), constitutes a frame for the contemplation of liturgical rites by the circle of believers gathered in the chevet. In the centre of the space, Siloé placed a tabernacle, now lost but whose image has come down to us in a well-known engraving made by Francisco Heylan at the beginning of the seventeenth century (Gómez-Moreno 1983: 69). Of the scholars mentioned above, it was Manfredo Tafuri who placed the most emphasis on the perspective nature of these radial passages, although he discussed this aspect in a general manner without analysing the specific geometry (Tafuri 1995: 144). The attribution to Siloé of the drawing in Barcelona explicitly reinforces the importance of the visual-perspective conception of space in the master's architectural thinking. For example, the conical geometry of the vault could be interpreted as the perspective deformation of a cylindrical barrel vault, in this case with precisely the opposite intention of that of the drawing-in other words, seeking to focus the viewer's attention on the altar. Meanwhile, the side walls adopt the form of triumphal arches reduced to a geometric scheme, integrating into the composition the perforations that penetrate the powerful mass of the buttresses. Viewed in a frontal projection, each of these triumphal 

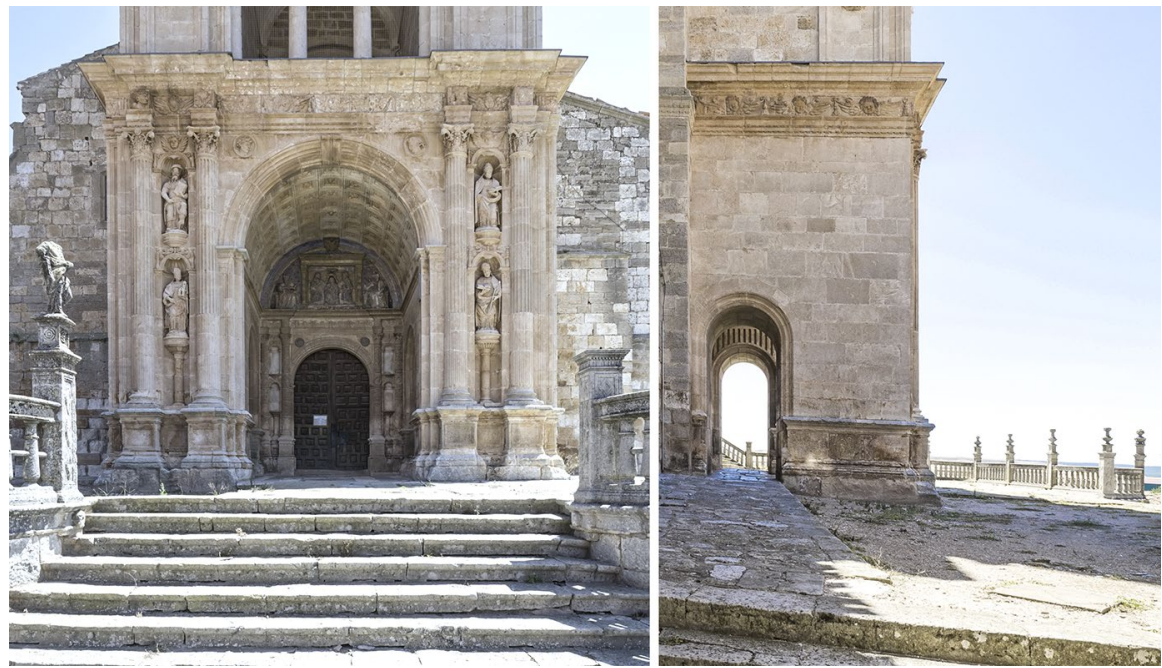

Fig. 15 Diego Siloé, atrium of Santa María del Campo in Burgos, after 1527

arches would display a distinct asymmetry, with the abutment on the side closest to the altar considerably wider than the one closest to the ambulatory. However, when the altar is viewed through the passage (Fig. 14b), and as a result of the perspective, the abutments of each triumphal arch, now foreshortened, appear as identical as if the arches were trying to recover their frontal appearance. The architectural frame therefore acquires a latent, celebratory energy which, together with the potency of the vault, accompanies the contemplation of the liturgy (Ampliato 1996: 100-104).

Barely 1 year before his major project for Granada, Siloé had begun another great architectural work, in Burgos province, with clear analogies to those mentioned here, albeit with less symbolic intensity. We are referring to the loggia, tower and main entrance of the church of Santa María del Campo (Fig. 15). Like the great buttresses that support the dome of Granada Cathedral, the powerful presence of the tower-facade is mitigated at the base by a passage with a barrel vault, in this case perfectly regular, which leads to the main facade. Again, as in Granada, transversal openings serve to lighten the space and multiply the directional references. A composition analogous to that of Santa María del Campo, although of less rigorous formal resolution, is the portico of the church of Santoyo, where Siloé's specific presence, or perhaps only his influence, can be detected (Mediavilla 1979: 112).

Another important element in the MNAC drawing - the central balcony over the second passage-has precedents in Siloé's work. One such example is the aforementioned Golden Staircase in Burgos Cathedral, from 1519 (see Fig. 4). Siloé designed a brilliant combination of primary and secondary planes in which the great high balcony acquires considerable prominence as the reference from below for the ascent and accentuating the projection of the crossing over the space from the upper entrance, where the staircase makes the transition between the inner space and the Camino de Santiago in its way across the city of Burgos. 

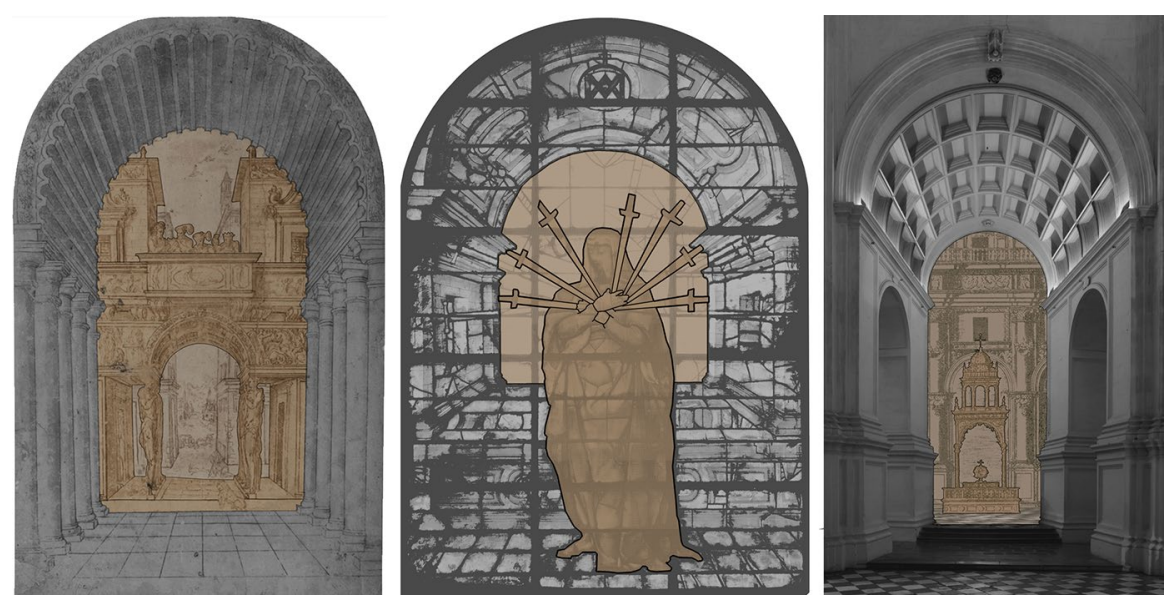

Fig. 16 Graphical analysis comparing the MNAC drawing, the stained-glass window of Our Lady of Sorrows and the passages in the chevet of Granada Cathedral, with the insertion of a fragment of the main altar taken from Heylan's engraving

To summarise our brief tour of selected works by Siloé, we have three crucial images: the drawing preserved in Barcelona, the stained-glass window in Granada Cathedral and the perspective passages in that same cathedral, three works that display a considerable coherence between their compositional themes (Fig. 16). In all three cases, a perspective barrel vault points to or frames, according to the case in question, a central theme in which the geometric projection serves not only as a technical instrument of spatial control but acquires an important symbolic value, either related to the inconsolable grief of our Lady of Sorrow, with the participation of the faithful in the communion rite, or perhaps to the celebration of architecture as an element for revitalising and transforming city and landscape.

\section{Italian Precedents and New References to Siloé's Work and the Granada Context}

Within the speculative framework of Diego Siloé's Italian sojourn, the recurring themes that we have just identified in his work clearly prompt new hypotheses. Siloé's use of conical perspective and the compositional-perspective use of the barrel vault are themes that take us back once again to the Florentine context of the second half of the fifteenth century and early decades of the sixteenth century, where they were the subject of intense research by artists. We need only to recall works such as Masaccio's Holy Trinity fresco in Santa Maria Novella in Florence or some of Donatello's bronze bas-reliefs, such as the ones he made for Sant'Antonio in Padua (Fig. 17a), in which the fluted treatment of the vaults displays similarities with the MNAC drawing.

However, it is in the work of Leon Battista Alberti where we find the most direct architectural references. Earl Rosenthal named some of Alberti's works as among 

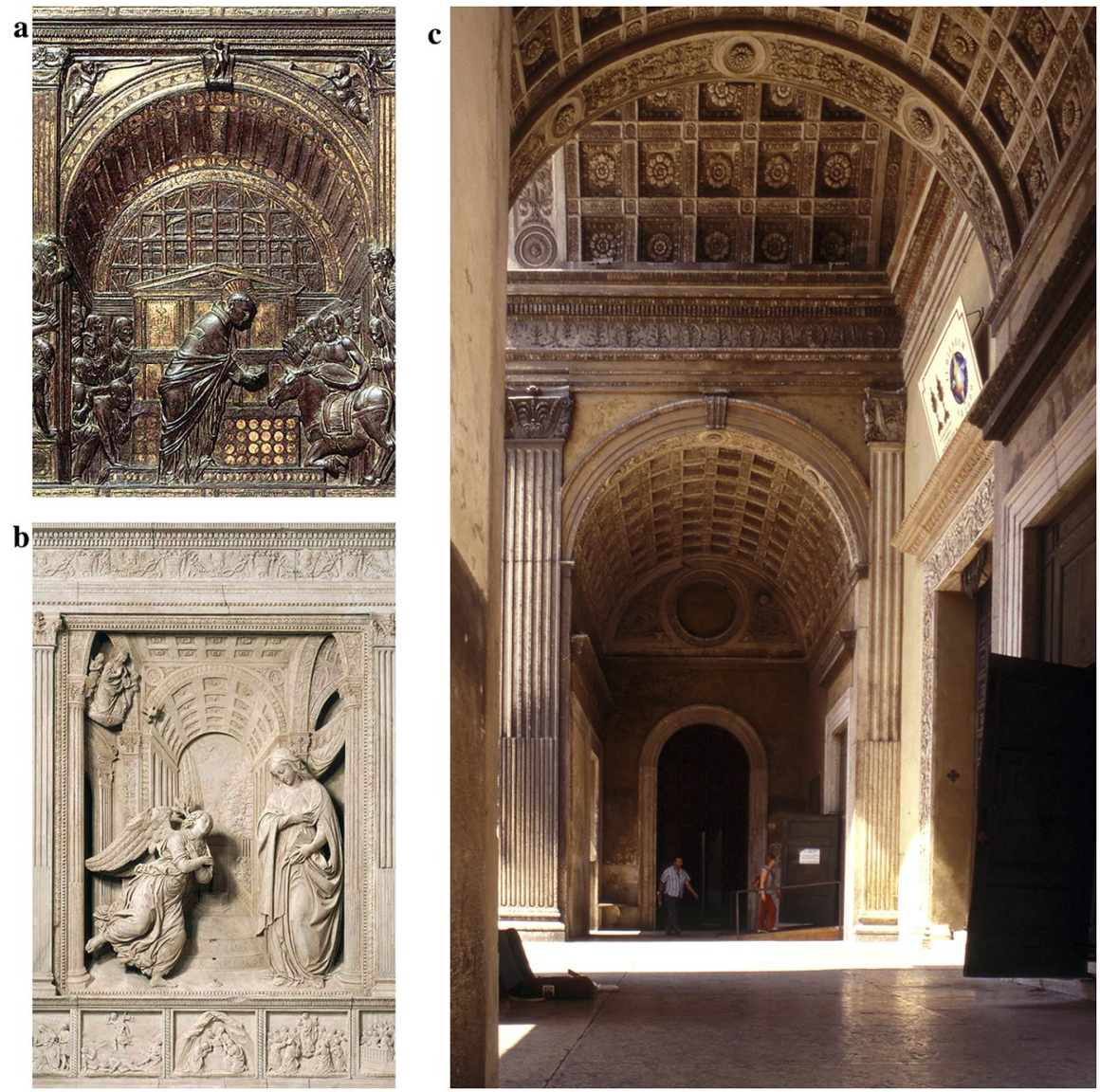

Fig. 17 a Donatello, fragment of Miracle of the Ass of Rimini in the Basilica di Sant'Antonio in Padua, 1447-50 (public domain image); b Benedetto da Maiano, altar in the Correale Chapel (fragment) in Santa Maria di Monteoliveto, Naples, 1489; c Leon Battista Alberti, atrium of the Church of Sant'Andrea in Mantua, after 1472

those closest to Siloé's architectural thinking (Rosenthal 1990: 74ff.). The church of Sant'Andrea in Mantua is upheld as a key architectural milestone in both the modern revival of the barrel vault and the compositional integration of the triumphal arch. The church portico is flanked by two perpendicular barrel vaults facing two different urban directions (Fig. 17c). The first one, with a higher vault, includes the main axis of the church and its facade. Another transversal one, with lower vaults, establishes a dialogue with its vicinity through the much-lauded Rotunda di San Lorenzo and the clock tower, within the context of a major urban renovation (Carrer 2007: 132ff.). After Alberti, Bramante would continue and expand on many of these experiences, with perspective effects like the one found in the virtual choir of Santa María presso San Satiro in Milan, and major plans like those of his project for San Pietro. 

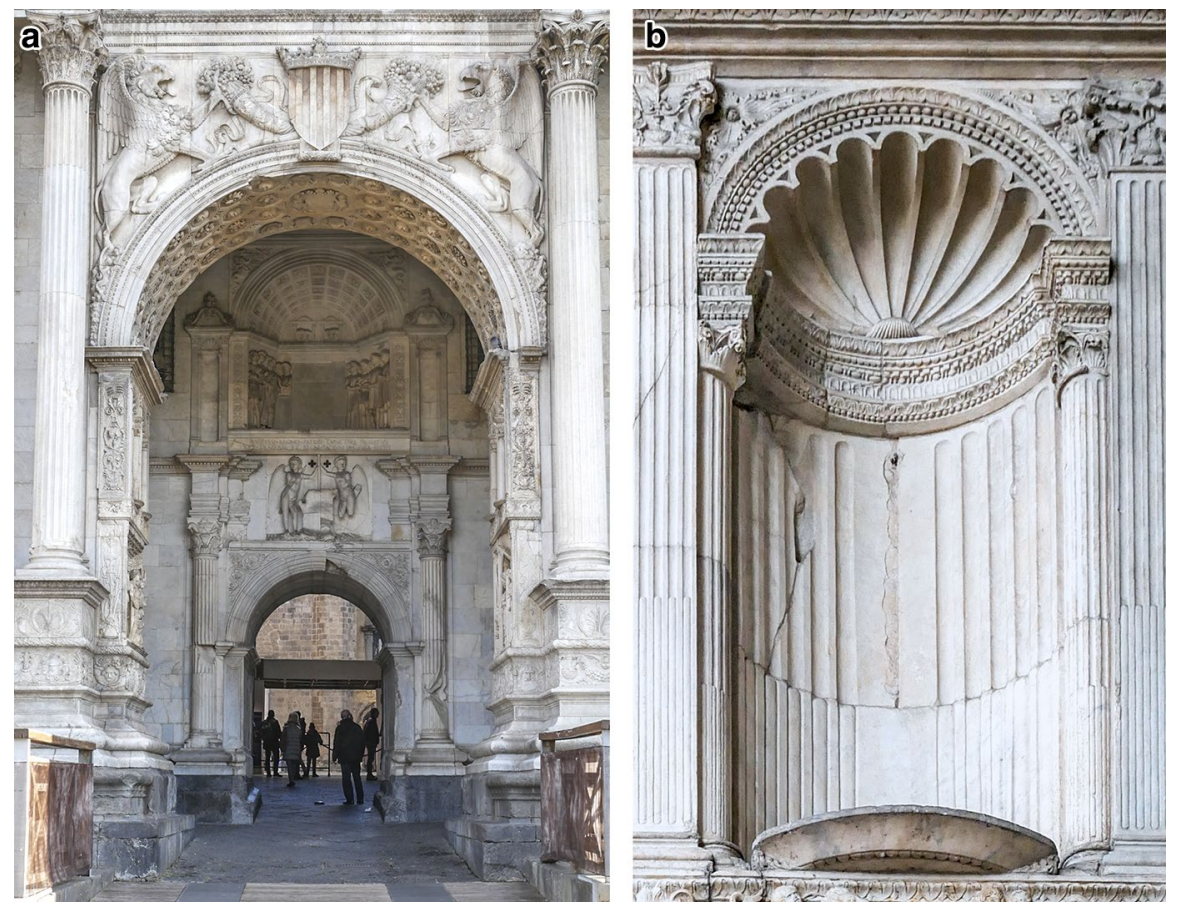

Fig. 18 a Triumphal Arch at Castel Nuovo, Naples, 1450-1468; b detail of a niche of the same arch

With regard to Naples, where Siloé lived temporarily, we find grand works in which the perspective composition includes a barrel vault to frame the scene. This is the case of the marquetry made by Fra Giocondo circa 1510 in the Certosa of San Martino and in the Old Sacristy at Santa Maria di Monteoliveto (Toajas 2007: 1-21). In this same church, the Correale chapel still has an altarpiece by Benedetto da Maiano, from 1489 (Fig. 17b), with a barrel vault in the background that imitates the Florentine models made by Maiano himself and other authors (Davies 2013: 898-921).

In the same city of Naples, the triumphal arch of Alfonso de Aragón (1450-1468), which some authors attribute to Alberti (Frommel 2008: 29ff.), could well have caught Siloé's attention because of its symbolic-representational nature, its organisation of primary and secondary planes or the use of the barrel vault and central vanishing point in certain bas-reliefs (Fig. 18a). But possibly even more significant in this arch are the surface claddings of some of the niches, which simulate the deployment on their surface of the fluting of a classical column (Fig. 18b). This theme seems to have held great appeal for Siloé. In the tomb of canon Diego de Santander (ca. 1523), situated in the cloister of Burgos Cathedral (Gómez-Moreno 1983: 51), he experimented with different adaptations on the side faces of the pilasters, on the rear wall of the niche and on the sides of the sarcophagus (Fig. 19a). The theme materialises again, clearly magnified, on the side walls of the passage at Santa María del Campo in Burgos (Fig. 19b). Most 

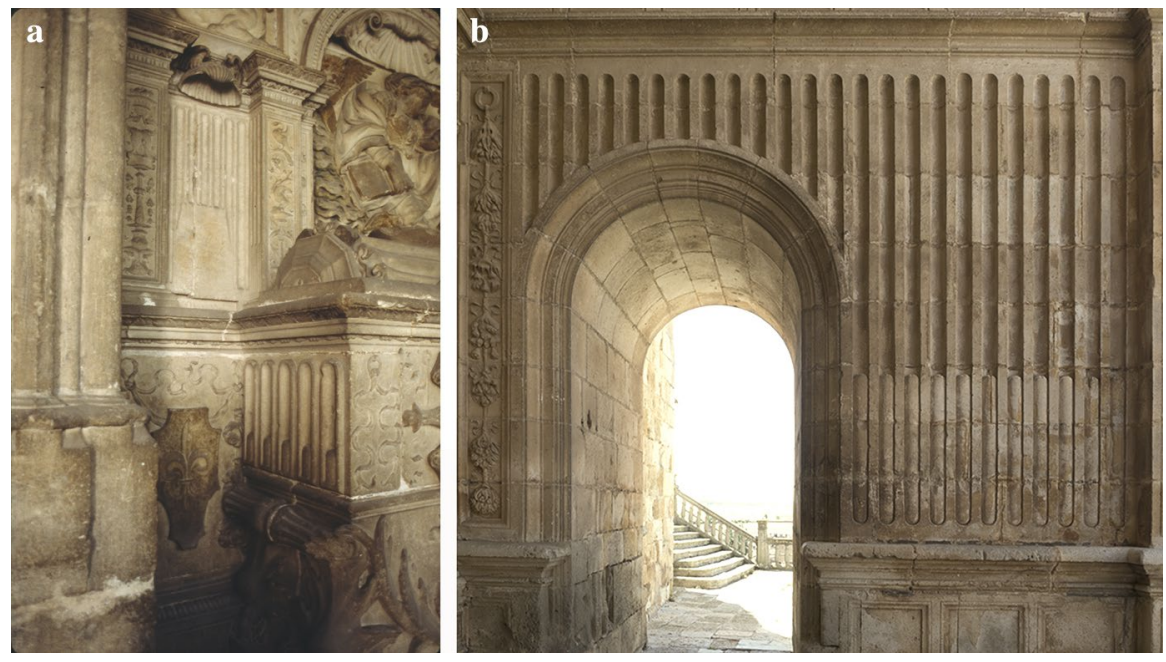

Fig. 19 a Diego Siloé, fragment of the tomb of Canon Diego de Santander, Burgos Cathedral, ca. 1523; b Diego Siloé, detail of the atrium of Santa María del Campo in Burgos, after 1527

importantly, this fluting theme finally appears filling the surface of the main chapel vault in a later work from Diego Siloé, the church of La Villa de Montefrío (Fig. 20). We cannot dismiss the hypothesis that the strange fluting on the vault in the drawing (see Fig. 1) may well be related to all these expressions.

Some niches of the triumphal arch of Alfonso de Aragón in Naples are surmounted by a shell in the vault intrados that appears on the front of the arch almost like a separate object (Fig. 18b), a solution frequently found in Italian architecture. In the tomb of Diego de Santander (Fig. 19a) the shells surmounting the central and side niches accentuate this impression of being independent objects. The vault in the MNAC drawing is foreshortened in a similar manner, also permitting the interpretation of the fluted surface as an object in itself, as if it were a superficial membrane attached to the tectonic mass of the vault.

Although other types of connections may be more emotional and difficult to view objectively, we do not want to end this tour without referencing a possible evocation of the city of Granada. In the perspective background of the drawing, a tiny urban landscape frames a river (Fig. 21a) that, in spite of later transformations, remind us of certain Romantic images of the Darro and its banks, with the mountains of Sierra Nevada in the distance (Fig. 21b). As noted by previous researchers, this urban background is framed by two symmetrical porticoes (Fig. 21c) with caryatids on the right and atlases on the left (Frommel and Parada 2014: 304), all in a position of submission, a gender distribution already employed by Siloé in his first work begun in Granada, the Real Monasterio de San Jerónimo (Callejón 2008: 351). A series of ornamental reliefs on the front plane could represent various commemorative scenes with the same illustrious figure, who we imagine could well be the emperor Charles V. The presence of musicians on the balcony and the portico with the figures emphasise a celebratory atmosphere. 

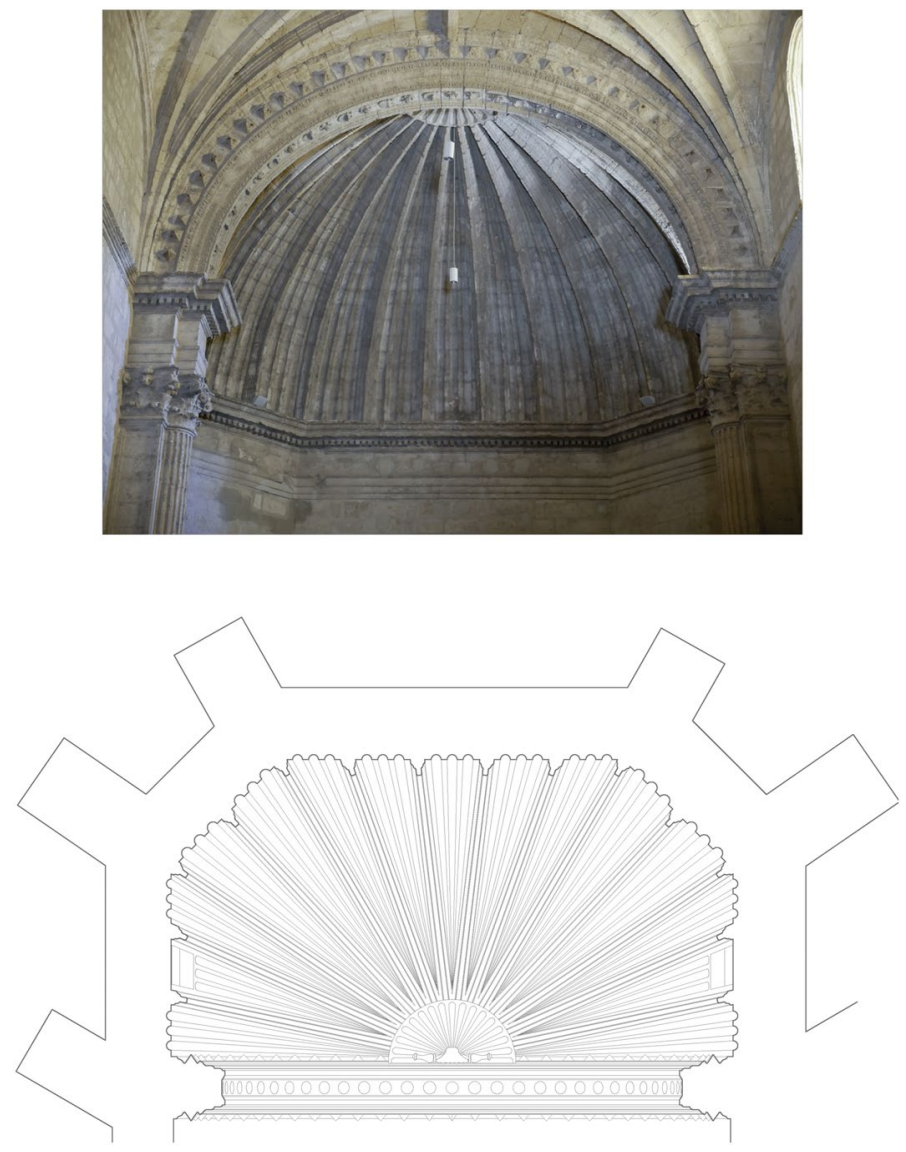

Fig. 20 Diego Siloé, church of La villa de Montefrío, plan and elevation of the chevet

\section{Conclusions}

In spite of the annotation on the document itself, the authorship of the drawing attributed to Diego Siloé and preserved in Barcelona cannot be definitively established, although the analyses presented here shed some additional light on this attribution. The drawing contains elements that were highly sophisticated and unfamiliar in the context of the first half of the sixteenth century in Spain, in terms of the application of one-point perspective as well as the use of the classical language and the arrangement of the architectural space. Our research highlights a complex architectural composition: a purposeful design masterfully combined with the rigorous use of perspective, despite a relatively fast execution, to the extent that it has been possible to reconstruct the space geometrically. It also demonstrates the presence of a symbolic use of perspective geometry, both in the drawing and in various examples of Siloé's work. All these aspects emphasise the more than plausible Italian training of the author of the drawing which, in the likely event that 

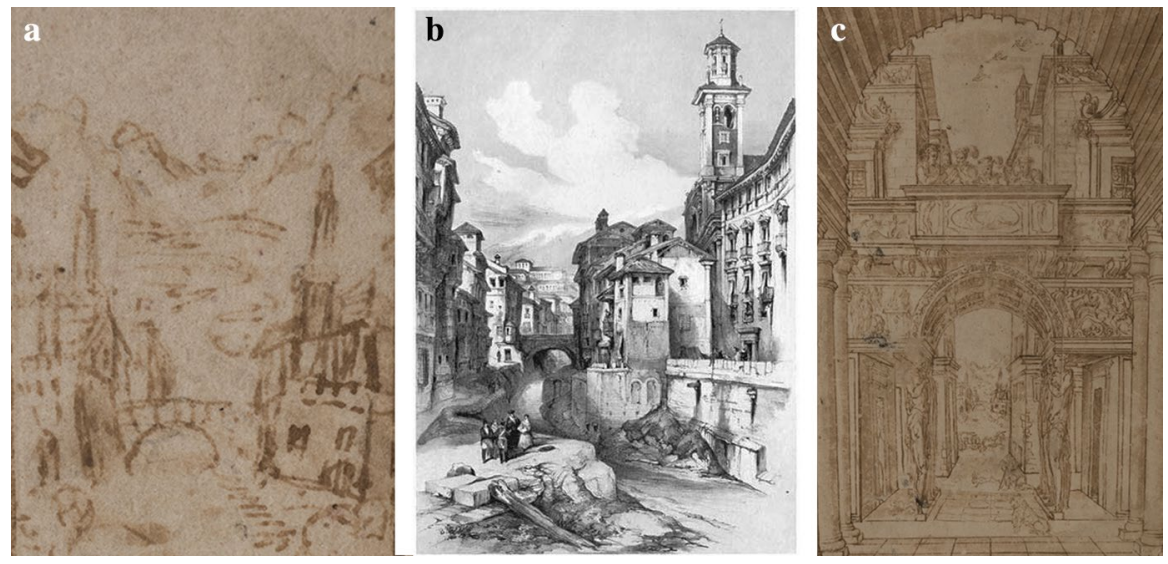

Fig. 21 a MNAC drawing, detail of the urban landscape depicted as the perspective background; b David Roberts, Banks of the River Darro, Granada, 1836 (Archivo Digital del Patronato de la Alhambra, Junta de Andalucía, ref. D-0049); c MNAC drawing, detail of the construction with the caryatid and atlas figures portico

this author was Siloé, would reinforce the idea of a longer sojourn of the master on Italian soil, including an important period of time in the city of Florence, in line with what the latest research on his sculpture in Naples is proposing (Naldi 2018).

The attribution of the drawing to Siloé, and of the knowledge that it represents, could open up new channels for interpreting his architectural work. In any case, and irrespective of the consideration of the drawing, the works analysed here, such as the stained-glass window in Granada Cathedral, the radial space of its chevet and other examples, furnish sufficient evidence of the creative use of Italian perspective and of a sophisticated conception of architecture.

Acknowledgements All drawings and photographs presented in this article are by the authors, unless the opposite is specifically indicated. Antonio Ampliato was funded by HAR 2016-76371-P, Government of Spain, 2017-2019.

\section{References}

Ampliato Briones, Antonio Luis. 1996. Muro, orden y espacio en la arquitectura del Renacimiento andaluz. Teoría y práctica en la obra de Diego Siloe, Andrés de Vandelvira y Hernán Ruiz II. Seville: Universidad de Sevilla y Consejería de Obras Públicas y Transportes.

Callejón Peláez, Antonio Luis. 2008. Primus inter heroes: damas y guerreros en la decoración del Monasterio de San Jerónimo. Granada: Mouliáa Map.

Carrer, Tomaso. 2007. The Triumphal Arch Motif in Sant'Andrea, Mantua: Respondeo and Rhetoric in Alberti's Architecture and Theory. Dissertation submitted for the degree of Doctor of Philosophy at the University of New South Wales. Sydney: Kensington campus.

Davies, Paul. 2013. Framing the Miraculous: The Devotional Functions of Perspective in Italian Renaissance Tabernacle Design. Art History 36(5): 898-921.

Domínguez Perela, Enrique. 1992. ¿La perspectiva en la pintura española el primer Renacimiento? Un problema sobre percepción de la profundidad. Arte, individuo y sociedad 4: 195-204.

Falomir Faus, Miguel. 2000. Diego de Siloe. Perspectiva. In: Carolus, dir. Checa Fernando. Toledo. 
Ferrer Valls, Teresa. 1991. La práctica escénica cortesana: de la época del emperador a la de Felipe III. Londres: Institució Valenciana d'Estudis i Investigació.

Frommel, Christoph Luitpold. 2008. Alberti e la porta triunfale di Castel Nuovo a Napoli. In: Annali di architettura: rivista del Centro Internazionale di Studi di Architettura Andrea Paladio 20: 13-36.

Frommel, Sabine and Manuel Parada López de Corselas. 2014. Serlianas durante el Renacimiento italiano y español: del triunfo de la religión católica al lenguaje imperial. In: El Imperio y las hispanias: de Trajano a Carlos V, eds. De María Sandro and Parada López de Corselas Manuel, 287-318.

Gallego Burín, Antonio. 1936. Documentos relativos al entallador y vidriero Juan del Campo. In: Cuadernos de Arte de la Universidad de Granada 1: 341-350.

Garriga Riera, Joaquím. 1988. Perspectiva. Obra atribuida a Diego de Siloé. In: L'època dels genis. Renaixement. Barroc, cat.65, 368. Gerona.

Gentil Baldrich, José María, 1998. El libro de perspectiva. In: Libro de Arquitectura: Hernán Ruiz II, 218-234. Seville: Fundación Sevillana de Electricidad.

Gómez-Moreno, Manuel. 1983. Las águilas del Renacimiento español (1941). Madrid: Xarait.

Gómez-Moreno, Manuel. 1988. Diego Siloe (1963). Granada: Universidad de Granada.

González Román, Carmen. 2006. "Los siete tratados de la perspectiva pratica". La primera versión del libro de Antonio de Torreblanca. In: Boletín de la Real Academia de Bellas Artes de San Fernando 102: $33-60$.

Hara, Mari Yoko. 2016. Capturing eyes and moving souls: Peruzzi's perspective set for La Calandria and the performative agency of architectural bodies. In: Renaissance Studies 31 (IV): 586-607.

Hernández Redondo, José Ignacio. 2000. Diego Siloe, aprendiz destacado en el taller de Felipe Bigarny. In: Locus Amoenus 5: 101-116.

Mediavilla, Aniano. 1979. Juan González y Juan García: entalladores de Santoyo. In: Publicaciones de la Institución Tello Téllez de Meneses 43: 103-113.

Naldi, Riccardo. 2002. Andrea Ferucci. Marmi gentili tra la Toscana e Napoli. Naples: Electa.

Naldi, Riccardo. 2018. Magnificence of Marble: Bartolomé Ordóñez and Diego de Silóe, sculpture of the renaissance in Naples. Munich: Hirmer.

Nieto Alcaide, Víctor, 1967. Tres dibujos preparatorios para la vidriera de "La Crucifixión" de Walburg. In: Archivo Español de Arte 164 (XLI): 267-274.

Nieto Alcaide Victor, 1973. Las vidrieras de la catedral de Granada. In: Corpus Vitrearum, Medii Aevi España, II. Granada: Universidad de Granada.

Ortega Vidal, Javier. 2001. Una muestra del dibujo de la arquitectura en la España Dorada. In: Las trazas de Juan de Herrera y sus seguidores, ed. López-Vidriero F.L., 337-416. Madrid: Fundación Marcelino Botín and Patrimonio Nacional.

Palladio, Andrea. 1980. I quattro libri dell'architecttura (1570). Milano: Edizione Il Polifilo.

Panofsky, Erwin. 1983. La perspectiva como forma simbólica (1927). Barcelona: Fabula Tusquets Editores.

Panofsky, Erwin. 1998. Los primitivos flamencos (1953). Madrid: Cátedra.

Parada López de Corselas, Manuel. 2018. La serliana del Palacio de Carlos V en Granada: arquitectura del poder entre España e Italia. In: El patio circular en la arquitectura del Renacimiento: de la casa de Mantegna al Palacio de Carlos V, eds. Pedro Antonio Galera Andreu and Sabine Frommel, 151-192. Seville: Universidad Internacional de Andalucía.

Pérez Sánchez, Alfonso. 1986. Historia del dibujo en España: de la Edad Media a Goya. Madrid: Cátedra.

Poggi, Paola M. 2005. Architectonica Perspectiva: La Prospettiva solida de Le Bacchidi e la volute. In: Baldassare Peruzzi 1481-1536, eds. Christoph L. Frommel, Arnaldo Bruschi, Howard Burns, Francesco Paolo Fiore and Pier Nicola Pagliara, 443-455. Venice: Marsilio.

Rosenthal, Earl. 1990. La Catedral de Granada: un estudio sobre el Renacimiento Español (1961). Granada: Universidad de Granada.

Sánchez Martín, Francisco Javier. 2012. La metrología renacentista: análisis científico y lexicográfico. In: Verba. Anuario galego de filoloxia 39: 107-133.

Serlio, Sebastiano. 1537. Libro IV - Regole generali di architettura. In L'architettura: I libri I-VII e Extraordinario nelle prime edizioni. Milano: Edizioni il Polifilo.

Steadman, Philip. 2020. Baldassare Peruzzi and Theatrical Scenery in Accelerated Perspective. Nexus Network Journal 22(3). https://doi.org/10.1007/s00004-020-00479-z.

Tafuri, Manfredo. 1995. Sobre el Renacimiento: Príncipes, ciudades, arquitectos (1992). Madrid, Cátedra. 
Toajas Roger, María Ángeles. 2007. Artistas hispanos en Italia en el siglo XVI: los viajes de Diego Siloe y Pedro Machuca. In: Viaje del Artista en La Edad Moderna, coords. Checa Cremades F. and González García J.L. Madrid: Editorial Complutense.

Vignola, Jacopo Barozzi da. 1985. Regla de los cinco órdenes de arquitectura (1562). Edición facsímil de la traducción castellana de 1593. Valencia: Ediciones Albatros.

Zurla, Michela, 2013. Domenico Fancelli, i re di Spagna e la congiuntura carrarese. In: Norma e capriccio: spagnoli in Italia agli esordi della maniera moderna, dirs. Mozzati Tomasso and Natali Antonio, 132-145. Firenze: Giunti.

Publisher's Note Springer Nature remains neutral with regard to jurisdictional claims in published maps and institutional affiliations.

Antonio Ampliato (Seville, 1958) is a doctor of architecture, professor of architectural graphic expression at the University of Seville. Since publishing his first book, Muro, orden y espacio en la arquitectura del Renacimiento andaluz [Wall, Order and Space in the Architecture of the Andalusian Renaissance] (1996, based on his doctoral thesis presented in 1991), he has conducted extensive research into the architecture of the Renaissance and Late Gothic in Andalusia. Adopting a hermeneutic approach, he has studied the idea of architectural space in the work of a number of sixteenth-century architects, such as Diego Siloé, Diego de Riaño, Andrés de Vandelvira and Hernán Ruiz II. He was the lead researcher of the R\&D project "Sevillian Cathedral Gothic: Architecture and City in the Areas of Influence of the Cathedral of Seville" (HAR2012-35152, Government of Spain, 2013-2016).Together with the doctor of history Juan Clemente Rodríguez-Estévez, he is currently the co-leader of the R\&D project: "Diego de Riaño, Diego Siloe and the Transition from Gothic to Renaissance in Spain" (HAR 2016-76371-P, Government of Spain, 2017-2019).

Eduardo Acosta (Seville, 1990) is an architect and master in repair and renovation of buildings (University of Seville). He has previously collaborated in the R\&D project HAR2012-35152 "Sevillian Cathedral Gothic: Architecture and City in the Areas of Influence of Seville Cathedral", funded by the Ministry of Economy and Competitiveness of the Government of Spain (2013-2016). He has carried out heritage analyses and surveys using 2D/3D scanning and photogrammetry (SfM). As a doctoral student in surveying and cultural heritage, he is currently studying the geometry and proportions in Diego Siloé's work as a key tool for understanding the new Renaissance ideas, while applying the latest surveying techniques for heritage analysis (laser scanning, photogrammetry, etc.) (2016 to present). He is member of the R\&D project HAR2016-76371-P "Diego de Riaño, Diego de Siloe and the Transition from Gothic to Renaissance in Spain/Architecture and City: Technology, Language and Spatial Conception", funded by the Government of Spain (2016 to present). 